\title{
Prostacyclin mediates endothelial COX-2- dependent neuroprotective effects during excitotoxic brain injury
}

This article was published in the following Dove Press journal:

Journal of Inflammation Research

2I May 2014

Number of times this article has been viewed

Ying $A n^{1,2}$

Natalya Belevych ${ }^{1,2}$

Yufen Wang ${ }^{1,2}$

Hao Zhang'

Jason S Nasse ${ }^{3}$

Harvey Herschman ${ }^{4}$

Qun Chen ${ }^{1,2}$

Andrew Tarr ${ }^{1,2}$

Xiaoyu Liu ${ }^{1,2}$

Ning Quan ${ }^{1,2}$

'Institute for Behavior Medicine Research, ${ }^{2}$ Department of Oral

Biology, College of Dentistry,

${ }^{3}$ Neuroscience Graduate Studies

Program, The Ohio State University,

Columbus, $\mathrm{OH}, \mathrm{USA} ;{ }^{4}$ Department of

Molecular and Medical Pharmacology,

UCLA, Los Angeles, CA, USA
Correspondence: Ning Quan Institute for Behavior Medicine Research, The Ohio State University, 460 Medical Center Drive, Room 232, Columbus,

$\mathrm{OH} 43210$, USA

$\mathrm{Tel}+\mathrm{I} 6143661037$

Fax + I 6I4 2746945

Email quan.14@osu.edu
Abstract: In a previous study, we found that intracerebral administration of excitotoxin $(R S)$-(tetrazole-5yl) glycine caused increased neural damage in the brain in an endothelial $C O X-2$ deleted mouse line (Tie2Cre $\left.C O X-2^{f t o x} f f o x\right)$. In this study, we investigated whether prostacyclin might mediate this endothelial COX-2-dependent neuroprotection. Administration of excitotoxin into the striatum induced the production of prostacyclin $\left(\mathrm{PGI}_{2}\right)$ in wild type, but not in endothelial $C O X-2$ deleted mice. Inhibition of $\mathrm{PGI}_{2}$ synthase exacerbated brain lesions induced by the excitotoxin in wild type, but not in endothelial $C O X-2$ deleted mice. Administration of a $\mathrm{PGI}_{2}$ agonist reduced neural damage in both wild type and endothelial $C O X-2$ deleted mice. Increased $\mathrm{PGI}_{2}$ synthase expression was found in infiltrating neutrophils. In an ex vivo assay, $\mathrm{PGI}_{2}$ reduced the excitotoxin-induced calcium influx into neurons, suggesting a cellular mechanism for $\mathrm{PGI}_{2}$ mediated neuroprotection. These results reveal that $\mathrm{PGI}_{2}$ mediates endothelial COX-2 dependent neuroprotection.

Keywords: neural injury, prostaglandins, neutrophil, conditional COX-2 deletion, $\mathrm{PGI}_{2}$

\section{Introduction}

Increased COX-2 expression occurs in acute brain injury conditions including cerebral ischemia, ${ }^{1}$ traumatic brain injury, ${ }^{2}$ spreading depression, ${ }^{3}$ and excitotoxic brain injury. ${ }^{4,5}$ We found recently in a model of excitotoxic brain injury that induced COX-2 expression mediates both neuroprotective and neurotoxic effects depending on the cell type of COX-2 expressing cells. Specifically, increased endothelial COX-2 expression confers a neuroprotective effect, whereas increased neuronal COX-2 expression confers a neurotoxic effect that is mediated by the neuronal production of prostaglandin E2. ${ }^{6}$

The COX enzyme catalyzes the production of prostaglandin $\mathrm{H} 2\left(\mathrm{PGH}_{2}\right)$ from free arachidonic acid. Arachidonic acid is first cyclized and oxygenated by COX to form prostaglandin $\mathrm{G} 2$, which is then reduced to form $\mathrm{PGH}_{2}$. $\mathrm{PGH}_{2}$ is the intermediate that serves as the substrate for the terminal prostanoid synthase enzymes. Besides prostaglandin $\mathrm{E} 2$, prostaglandin $\mathrm{G} 2\left(\mathrm{PGD}_{2}\right)$, prostacyclin $\left(\mathrm{PGI}_{2}\right)$, and thromboxane can be produced downstream of COX. ${ }^{7}$ Some of the COX dependent prostanoids have been reported to provide neuroprotective effects during acute brain injury. These include $\mathrm{PGI}_{2}$ and $\mathrm{PGD}_{2}$. For example, physiological concentrations of $\mathrm{PGD}_{2}$ have been shown to rescue neurons in an in vitro model of excitotoxicity, ${ }^{8}$ and cerebral ischemia-induced brain damage can be reduced by a $\mathrm{PGI}_{2}$ agonist. ${ }^{9}$ In the periphery, $\mathrm{PGI}_{2}$ is known to have vasodilation properties and it is used to relieve pulmonary hypertension. ${ }^{10}$ In the central nervous system (CNS), endothelial $\mathrm{PGI}_{2}$ production has been shown to exhibit neuroprotective activity in a model of cerebral ischemia. ${ }^{11}$ Because our observed 
neuroprotective effects were associated with endothelial COX-2 expression, we sought to investigate the role of $\mathrm{PGI}_{2}$ in mediating this neuroprotection in the present study.

\section{Material and methods}

\section{Animals}

Tie2Cre COX-2 $2^{f o x}$ ffox mice were generated by cross breeding Tie2Cre; $C O X-2^{+/+}$transgenic mice (stock \# 004128; The Jackson Laboratory, Bar Harbor, ME, USA) with $C O X-2^{f f o x f f o x}$ mice. LysMCre COX-2 $2^{f o x f f o x}$ mice were generously provided by Dr Reddy (Department of Medicine, University of California, Los Angeles; Los Angeles, CA,

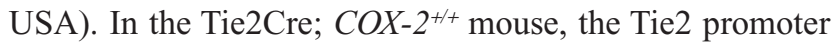
restricts Cre recombinase expression in endothelial cells and hematopoietic cells during embryogenesis and adulthood. ${ }^{12}$ Therefore, the COX-2 gene is selectively deleted in endothelial cells and hematopoietic cells in Tie2Cre $C O X-2^{f t o x f f o x}$ mice. In LysMCre; $\mathrm{COX}-2^{+++}$mice, transgenic expression of Cre recombinase is restricted to myeloid lineage cells; consequently, $C O X-2$ is deleted specifically in myeloid cells in

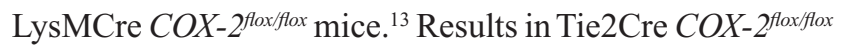

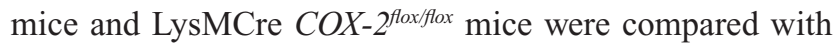
their respective Cre-negative $C O X-2^{f f o x f f o x}$ littermates. Mice of 10-16 weeks of age, with body weights of 25-30 g, were used in experimental procedures. All procedures were approved by the Ohio State University Animal Care and Use Committee.

\section{Genotyping}

Genomic DNA was purified from mouse tail tissue. Briefly, tail samples were frozen for at least 15 minutes at $-80^{\circ} \mathrm{C}$. Each sample was incubated with $500 \mu \mathrm{L}$ of lysis buffer (10 mM Tris $\mathrm{HCl} \mathrm{pH} 8.0 ; 100 \mathrm{mM}$ ethylenediaminetetraacetic acid; $0.5 \%$ sodium dodecyl sulfate; $0.2 \mathrm{mg} / \mathrm{mL}$ ribonuclease $\mathrm{A} ; 1 \mathrm{mg} / \mathrm{mL}$ proteinase $\mathrm{K}$ ) for 2 hours at $56^{\circ} \mathrm{C}$ with repeated agitation. Samples were then centrifuged at 13,000 rpm for 10 minutes to remove tissue residue from the lysate. Genomic DNA was precipitated by adding $500 \mu \mathrm{L}$ isopropanol and was washed with $1 \mathrm{~mL}$ ice-cold $70 \%$ ethanol. DNA pellets were dissolved in $50 \mu \mathrm{L}$ of $5 \mathrm{mM}$ Tris $\mathrm{HCl}$ buffer $(\mathrm{pH}$ 8.5 ) by incubation at $65^{\circ} \mathrm{C}$ for 10 minutes.

To detect the presence of Cre recombinase by polymerase chain reaction, the following primer set was used for the generation of a $300 \mathrm{bp}$ amplicon: Cre300F: 5'-CGATGCAACGAGTGATGAGG-3' and Cre300R: 5'-CGCATAACCAGTGAAACAGC-3'. To detect the knockout $\mathrm{COX}-2$ alleles, the following primer set was used: $\mathrm{COX}-2 \mathrm{E} 3 \mathrm{~F} 1$ : 5'-AATTACTGCTGAAGCCCACC-3' and COX-2I5R1:
5'-GAATCTCCTAGAACTGACTGG-3'. The COX-2 floxed allele amplicon is $2,670 \mathrm{bp}$ while the same primer set detects the COX-2 deleted allele as a 1,054 bp amplicon. Detailed description on how these primers can be used to differentiate different genotypes has been published previously. ${ }^{14}$

\section{Reagents}

(RS)-(Tetrazol-5-yl)glycine (5 $\mu \mathrm{M}, \mathrm{TZG}$; Tocris Bioscience, Ellisville, MO, USA), a potent $N$-Methyl-D-aspartate (NMDA) agonist, was dissolved in phosphate-buffered saline (PBS) (pH 7.4; Thermo Fisher Scientific, Waltham, MA, USA) to induce pharmacological excitotoxic lesions in the brain. NS-398 (2 mg/kg; Cayman Chemical Company, Ann Arbor, MI, USA) and MRE-269 (1 mg/kg; Cayman Chemical Company) were dissolved in dimethyl sulfoxide before being further diluted in PBS. Tranylcypromine $(10 \mathrm{mg} / \mathrm{kg}$; Enzo Life Sciences Inc., Farmingdale, NY, USA) was dissolved in PBS ( $\mathrm{pH}$ 7.4). Antibodies used for immunohistochemistry were rabbit anti-mouse $\mathrm{PGI}_{2}$ synthase (PGIS) (Abcam, Cambridge, MA, USA), rat anti-mouse CD45 (BD Biosciences, San Jose, CA, USA), biotinylated anti-mouse Ly6G (BD Biosciences), and rat anti-mouse F4/80 (ABD Serotec, Raleigh, NC, USA). Antibodies used for flow cytometry were fluorescein isothiocyanate-conjugated anti-Ly6G and peridinin chlorophyll protein-conjugated anti-Gr1 (BD Biosciences).

\section{Intrastriatal injection of NMDA agonist}

Mice were anaesthetized by intraperitoneal injection (IP) of $100 \mathrm{mg} / \mathrm{kg}$ of Nembutal (Abbott Laboratories, Abbott Park, IL, USA) and then securely fastened onto a small animal stereotaxic frame with a mouse head holder (David Kopf Instruments, Tujunga, CA, USA). A burr hole was drilled and an injection cannula (28 gauge) was lowered into the center of the right striatum (anterior, $0.5 \mathrm{~mm}$; lateral, $2.0 \mathrm{~mm}$; ventral, $4.0 \mathrm{~mm}$ to bregma) according to a mouse brain atlas. ${ }^{15}$ Ten microliters of TZG $(5 \mu \mathrm{M})$ or sterile PBS was injected at a rate of $0.8 \mu \mathrm{L} / \mathrm{min}$ using a microinjection system (KDS Scientific, Holliston, MA, USA). Needles were left unmoved for an additional 5 minutes after fluid injection, to prevent backflow. Wounds were then sutured and animals were allowed to recover from anesthesia. Animals were sacrificed and brain samples were collected at 4, 8, 12, or 24 hours after the intrastriatal injection.

\section{Hematoxylin and eosin staining}

Fresh-frozen brain sections were allowed to air-dry for at least 15 minutes before fixing in $95 \%$ alcohol for 5 minutes. Sections were then briefly rinsed in water and stained in 
Mayer's hematoxylin solution (Sigma-Aldrich Co, St Louis, MO) for 15 minutes. After rinsing in water five times, slides were stained in $1 \%$ eosin Y solution (Thermo Fisher Scientific) for 3 minutes. Slides were then dipped five to ten times in $95 \%$ and $100 \%$ alcohol prior to cover-slipping using Permount (Thermo Fisher Scientific).

\section{Determination of lesion volumes}

Brains were sectioned on a cryostat to generate $20 \mu \mathrm{m}$ sections throughout the entire striatum. Every third coronal section was collected and stained. Lesion areas on each section were quantified using an image analyzer (ImageJ; National Institutes of Health, Bethesda, MD, USA). The entire lesion area was calculated to determine the lesion volume. All lesion sizes were quantified by a person blinded to the treatment groups.

\section{Immunohistochemistry (IHC)}

Fresh-frozen coronal brain sections were fixed in an acetone/ alcohol mixture (3:1) for 5 minutes. The sections were treated with glucose oxidase and sodium azide to reduce background interference. They were then incubated with rabbit antiPGIS antibody (1:800) followed by an anti-rabbit secondary antibody (1:200). The labeling was amplified with the ABC solution (Vector Laboratories, Inc., Burlingame, CA, USA) and visualized with a DAB peroxidase substrate kit (Vector Laboratories, Inc.). To identify the types of cells expressing PGIS, double-label IHC was performed. PGIS-stained cells were double-labeled with antibodies directed against the cellular protein markers anti-CD45 (pan-leukocytes; 1:200), anti-Ly6G (neutrophils; 1:1000), or anti-F4/80 (monocytes; $1: 600)$. The labeling of these cell-type markers was visualized with Cy-2 (1:400) or Cy3-streptavidin (1:400; Jackson ImmunoResearch Laboratories, Inc., West Grove, PA, USA). Negative controls (ie, omission of primary antibody) were used to determine specificity of antibody binding.

\section{Semiquantitative analysis of PGIS and CD45 immunoreactivity}

Relative values of PGIS and CD45 immunoreactivity are given as estimates of the density of immunohistochemical staining. Two coronal sections ( $0.5 \mathrm{~mm}$ anterior to bregma) per animal for three animals per group were analyzed (Table 1). Mice injected with saline were used as controls.

A five-point scale was used to rate the data: 5) +++ , high density of cellular signals; 4) ++ , moderate density; 3) + , low density; 2) \pm , single cellular signals in some cases; and 1) -, no signals. The values for two sections per
Table I Semiquantitative analysis of TZG-induced PGIS and CD45 immunoreactivity

$\begin{array}{lllll}\text { COX-2 }^{\text {flox/flox }} & & \begin{array}{l}\text { Tie2Cre } \\ \text { COX-2 }\end{array} & \text { Controx/flox } \\ & \begin{array}{l}\text { TZG plus } \\ \text { NS-398 }\end{array} & & \text { TZG } & \text { Saline } \\ & & & \end{array}$

\begin{tabular}{|c|c|c|c|c|}
\hline \multicolumn{5}{|c|}{$\begin{array}{l}\text { A. PGIS and CD45 striatal in } \\
\text { TZG or saline injection }\end{array}$} \\
\hline PGIS & ++ & - & - & - \\
\hline \multirow[t]{2}{*}{ CD45 } & +++ & +++ & +++ & - \\
\hline & 4 hours & 8 hours & 12 hours & $24 \mathrm{hc}$ \\
\hline
\end{tabular}

B. Time course of PGIS striatal immunoreactivity in wild type mice after TZG injection

PGIS

Notes: +++ , high density of cellular signals; ++, moderate density; + , low density - , no signal.

Abbreviations: PGIS, prostacyclin synthase; TZG, (RS)-(tetrazol-5-yl)glycine.

animal were averaged, and the means of these averages for the three animals per group are presented. Quantification of the immunoreactivity data was performed by an investigator blinded to the treatment groups. Negative controls (ie, omission of primary antibody) were used to determine specificity of antibody binding.

\section{Depletion of neutrophils}

Mice were injected IP with $100 \mu \mathrm{g}$ of an anti-neutrophil antibody (clone 1A8; BD Biosciences) 24 hours before intrastriatal injection of TZG. Control animals were injected IP with PBS. Twenty-four hours after TZG injection, blood and brain samples were collected. Neutrophil depletion was confirmed by analysis of the blood samples for Ly6G and Gr1 double-labeled cells using flow cytometry and by IHC labeling of Ly6G in brain sections.

\section{Flow cytometry}

Blood samples were collected by cardiac puncture. Red blood cells were lysed by using red blood cell lysis buffer ( $4.4 \mathrm{~g}$ $\mathrm{NH}_{4} \mathrm{Cl}, 0.5 \mathrm{~g} \mathrm{KHCO}_{3}$, and $0.019 \mathrm{~g}$ ethylenediaminetetraacetic acid in $500 \mathrm{~mL}$ distilled water, $\mathrm{pH}$ 7.2-7.4) for 2 minutes at room temperature. Cells were washed and incubated with Fc receptor block (BD Biosciences) for 10 minutes at $4^{\circ} \mathrm{C}$. Cells were then washed and incubated with fluorescein isothiocyanate-conjugated anti-Ly6G and peridinin chlorophyll protein-conjugated anti-Gr1 for 45 minutes at $4^{\circ} \mathrm{C}$ in the dark. Cells were washed and then resuspended in fluorescence activated cell sorting (FACS) buffer ( $2 \%$ fetal bovine serum [FBS] in PBS with $1 \mathrm{mg} / \mathrm{mL}$ sodium azide). Nonspecific binding was determined by using isotype-matched control antibodies. Analysis of stained cells was performed with a 
Becton-Dickinson FACS Caliber four color flow cytometer (BD, Franklin Lakes, NJ, USA). Ten thousand events were recorded for each sample and isotype match-conjugate. Flow cytometric data were analyzed with FlowJo software (TreeStar Inc., Ashland, OR, USA).

\section{Measurement of $\mathrm{PGI}_{2}$ level}

Mice received intrastriatal injection of $\mathrm{TZG}$ or saline. Animals were euthanized by decapitation 12 hours after injection. A $4 \mathrm{~mm}$-thick coronal striatal brain section including the needle track (from $2.5 \mathrm{~mm}$ to $-1.5 \mathrm{~mm}$ relative to bregma) was collected from each animal, placed in 1 $\mathrm{mL}$ ice-cold PBS, and homogenized thoroughly. All tested samples weighed $11.6 \mathrm{mg}$. Samples were centrifuged at $13,000 \mathrm{rpm}$ at $4^{\circ} \mathrm{C}$ for 10 minutes to remove tissue residue, and supernatants were saved until assays were performed. The level of $\mathrm{PGI}_{2}$ was measured using an EIA kit (Cayman Chemical Company) to detect 6-keto prostaglandin $\mathrm{fl} \alpha$, the stable metabolite of $\mathrm{PGI}_{2}$. All samples were run in triplicates to determine variability. Relative abundant changes were expressed as the ratio of (6-keto prostaglandin $f 1 \alpha$ present in striatal samples from mice injected with TZG) divided by (6-keto prostaglandin $\mathrm{fl} \alpha$ present in striatal samples from mice injected with saline).

\section{Calcium imaging}

Striatal slices were cut from P7 to P9 wild type rat pups to $350 \mu \mathrm{m}$-thick sections on a vibratome and were allowed to recover for 1 hour at $32^{\circ} \mathrm{C}$. Sections were then incubated in an artificial cerebral-spinal fluid (ACSF) bath containing $25 \mu \mathrm{M}$ Quest Fluo-8 AM (AAT-Bioquest, Inc., Sunnyvale, CA, USA) with $0.01 \%$ dimethyl sulfoxide and $0.002 \%$ Pluronic-F127 for 20 minutes, rinsed twice for 30 minutes each, and held at room temperature until the beginning of each experiment. Individual slices were imaged on a fixed-stage upright microscope equipped with a custom made perfusion chamber. Imaging experiments were conducted using a Visitech Infinity 3 confocal live-cell imaging system (Visitech International, Sunderland, UK) within the OSU campus microscopy and imaging facility (CMIF). During the imaging experiments, all slices were continuously perfused with warmed $\left(32^{\circ} \mathrm{C}\right)$ ACSF at a rate of $2 \mathrm{~mL} / \mathrm{min}$. All drugs were delivered through a manifold system directly in line with the perfusion chamber. Neurons in a given slice preparation were first tested for baseline NMDA receptor activation by perfusing $5 \mu \mathrm{M} \mathrm{TZG}$ through the chamber for 30 seconds while the section was imaged at 6.7 frames/second. TZG induced fluorescence in individual neurons was measured off-line using Metamorph imaging software (Molecular Devices LLC, Sunnyvale, CA, USA) and set to be $100 \%$. After a 2.5-minutes ACSF washout, the slice was tested again to determine the effect of $\mathrm{PGI}_{2}$ on TZG-induced calcium influx: the $\mathrm{PGI}_{2}$ agonist MRE-269 $(0.1 \mu \mathrm{M})$ was perfused through the chamber for 20 minutes prior to a second $30 \mathrm{sec}$ perfusion of TZG. Fluorescence intensity in individual neurons after the second TZG perfusion was normalized to the fluorescence intensity of the same neurons after the first TZG perfusion (similar to Huang et al). ${ }^{16}$ To test for the possibility of dye rundown or NMDA receptor desensitization, control experiments were performed where only ACSF was perfused for 20 minutes between the first and second application of TZG.

\section{Statistical analysis}

Data were analyzed, as appropriate, by one-way or two-way analysis of variance followed by post hoc Student's $t$-tests where appropriate. An alpha level of $P \leq 0.05$ was used for the rejection of the null hypothesis.

\section{Results $\mathrm{PGI}_{2}$ mediates the endothelial COX-2- dependent neuroprotective effect following excitotoxin injection}

We first measured the level of 6-keto prostaglandin $\mathrm{fl} \alpha$, the major stable metabolite of $\mathrm{PGI}_{2}$, in brain sections 12 hours after TZG injection. 6-Keto prostaglandin fl $\alpha$ levels in striatal sections from TZG-treated $C O X-2^{\text {flox/flox }}$ mice were significantly increased (nearly twofold) relative to the 6-keto prostaglandin fl $\alpha$ levels in saline injected controls (Figure 1A). In contrast, a much smaller increase in 6-keto prostaglandin fl $\alpha$ levels was observed following TZG injection in Tie2Cre $C O X-2^{\text {flox/flox }}$ mice relative to their saline-injected controls (Figure 1A); TZG induced 6-keto prostaglandin $\mathrm{fl} \alpha$ was significantly higher in the wild type $C O X-2^{\text {flox/flox }}$ mice than in the Tie2Cre $C O X-2^{\text {flox/flox }}$ mice $(P<0.01$; Figure 1A).

If $\mathrm{PGI}_{2}$ does indeed mediate the endothelial COX-2dependent neuroprotection to excitotoxin treatment, then inhibition of PGIS should prevent the neuroprotective effect and lead to increased lesion volume. IP administration of tranylcypromine $(10 \mathrm{mg} / \mathrm{kg})$, an inhibitor of PGIS, 1 hour before the TZG injection resulted in an increased lesion vol-

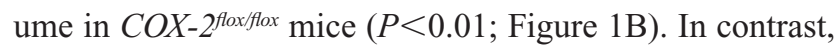
there was no change in excitotoxin-induced lesion volume

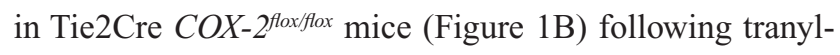
cypromine treatment. 


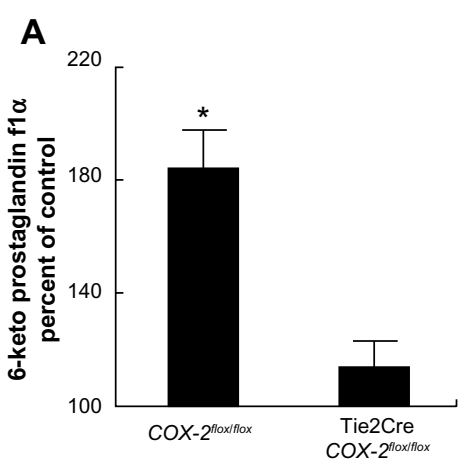

C

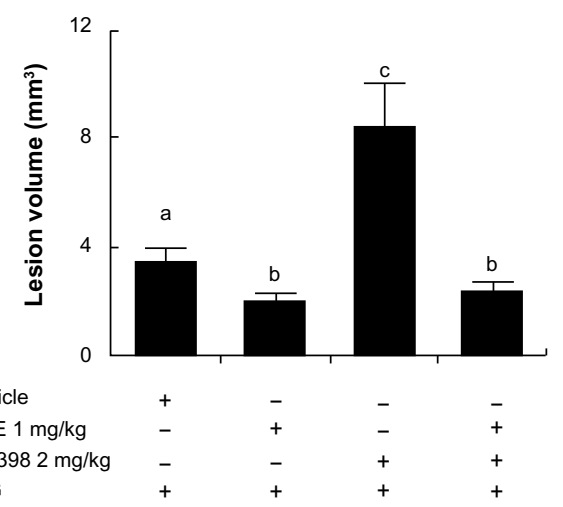

B

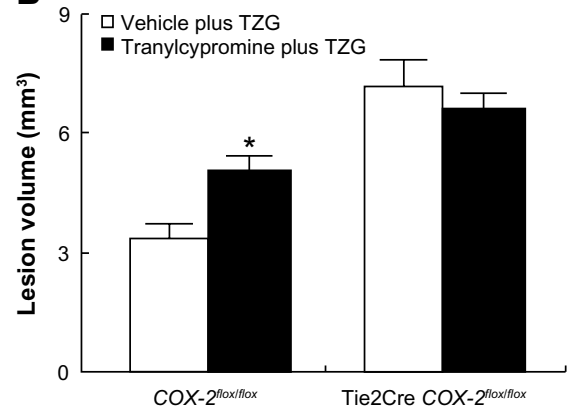

D $\square$ Vehicle plus TZG

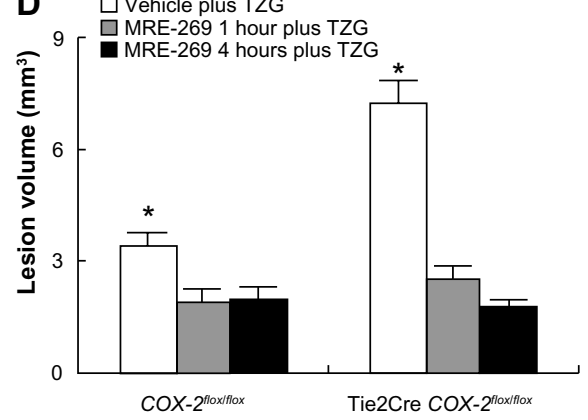

Figure I PGI ${ }_{2}$ mediates the endothelial COX-2-dependent neuroprotective effect following excitotoxin injection.

Notes: (A) The percent of $\mathrm{PGI}_{2}$ stable metabolite (6-keto prostaglandin $\mathrm{fl} \alpha$ ) 12 hours after TZG injection in COX-2 flox/flox and Tie2Cre COX-2 flox/flox mice relative to saline controls. (B) Twenty-four-hour assessment of TZG induced lesion volume with or without the pretreatment of the PGIS inhibitor tranylcypromine in COX-2floxffox mice and Tie2Cre COX-2 floxfflox mice. (C) Twenty-four-hour assessment of TZG-induced lesion volume in COX-2 floxffox mice with or without treatment of the PGI ${ }_{2}$ stable analogue MRE-269 and/or low-dose NS-398. (D) Twenty-four-hour assessment of lesion volume in TZG injected COX-2 ffoxfflox and Tie2Cre COX-2 floxfflox mice following I or 4 hours pretreatment with MRE269. Bars represent group means \pm SEM. Means with different letters $(\mathbf{a}-\mathbf{C})$ are significantly different from one another in $(\mathbf{C})(P<0.05$ for all). $*$ Represents a significant effect of TZG (A), tranylcypromine (B), and MRE-269 (D) compared to their respective control groups ( $P \leq 0.05$ for all). $N=5$ in all experimental groups.

Abbreviations: +, positive; -, negative; PGI, prostacyclin; PGIS, prostacyclin synthase; SEM, standard error; TZG, (RS)-(tetrazol-5-yl)glycine.

If $\mathrm{PGI}_{2}$ mediates the endothelial COX-2-dependent neuroprotection to excitotoxin treatment, then administration of a stable $\mathrm{PGI}_{2}$ analogue should reduce TZG-induced lesions. IP administration of the stable PGI $_{2}$ analogue MRE-269 $(1 \mathrm{mg} / \mathrm{kg})$ significantly reduced the injury volume following TZG injection relative to vehicle treated mice receiving TZG injections $(P<0.05$; Figure $1 C)$. We showed previously that administration of a low dose $(2 \mathrm{mg} / \mathrm{kg})$ of the selective COX-2 inhibitor (NS-398) resulted in exacerbated neurotoxicity. ${ }^{6}$ We then tested whether administration of a $\mathrm{PGI}_{2}$ stable analogue would supplement the endogenously produced $\mathrm{PGI}_{2}$ and reduce the exaggerated neurotoxicity induced by TZG administration to wild type mice in the presence of the low level of NS-398. ${ }^{6}$ As predicted, treatment with MRE269 strongly diminished the lesion-enlarging effect of the low-dose NS-398 for TZG induced neurotoxicity $(P<0.05$; Figure 1C).

Lastly, to explore the therapeutic potential of MRE-269, MRE-269 was injected 4 hours after the TZG injection, in

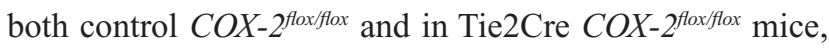

in which the neuroprotective effect of the endothelial COX2-expressing cells had been eliminated by targeted gene deletion in our previous study. ${ }^{6}$ Results show post-injury treatment with MRE-269 was able to significantly reduce neural damage in both wild type mice and Tie2Cre COX-2foxffox mice $(P<0.05$ for both; Figure 1D). These results indicate that the stable $\mathrm{PGI}_{2}$ analogues had a relatively broad timewindow in treating acute excitotoxic brain injury.

\section{Presence of PGIS+ and CD45+ cells following TZG injection}

The preceding results suggest that the terminal enzyme for $\mathrm{PGI}_{2}$ synthesis, PGIS, should be present in the $\mathrm{PGI}_{2}-$ producing cells responsible for the neuroprotective effects. Results show PGIS+ cells were not detectable in the brain 12 hours after saline injection in $C O X-2^{f f o x f f o x}$ mice (Figure 2A) or Tie2Cre COX-2 ffoxffox mice (data not shown). PGIS+ cells were, however, scattered in the lesion core of $C O X-2^{f f o x f f o x}$ mice following TZG injection (Figure 2B). In contrast, PGIS+ cells were not present in Tie2Cre $C O X-2^{f f o x f f o x}$ mice after TZG 


\section{Saline}

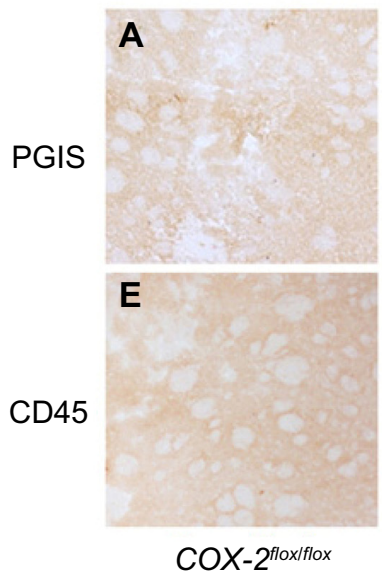

TZG
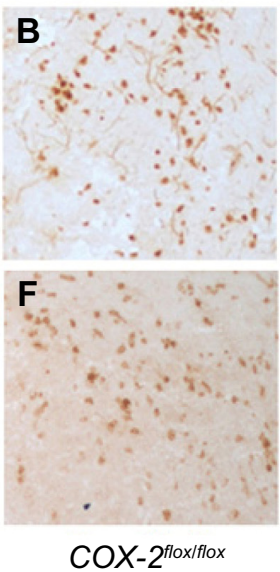

$\operatorname{cOX}-2^{\text {flox }}$ flox
TZG
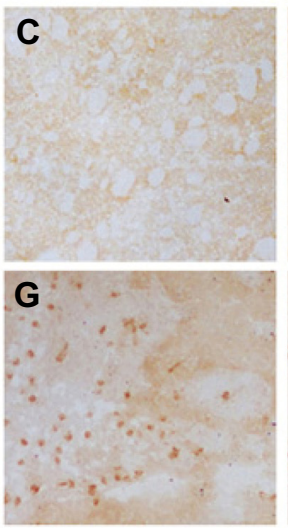

Tie2Cre COX-2flox/flox
NS-398 plus TZG
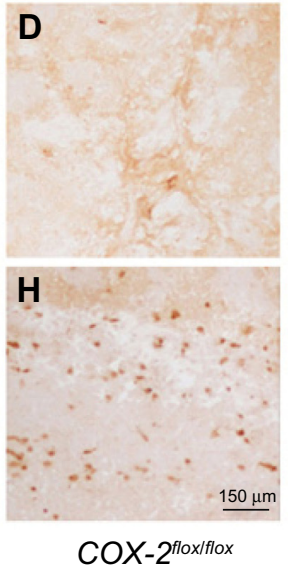

1

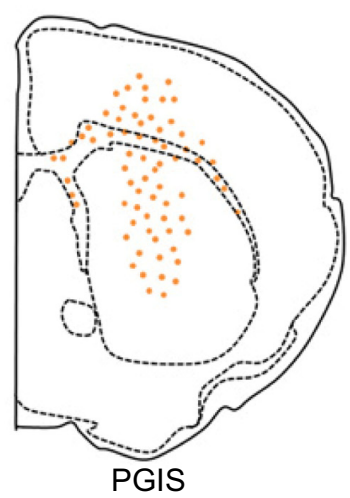

$\mathrm{J}$

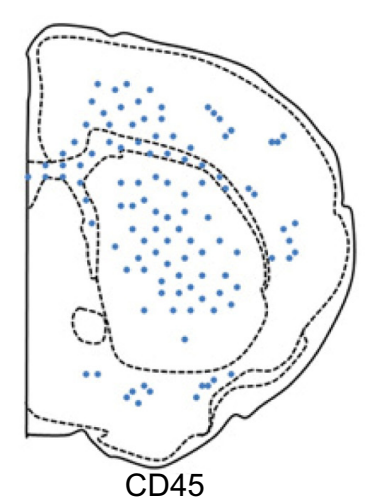

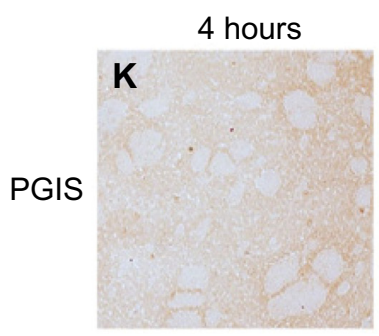

8 hours
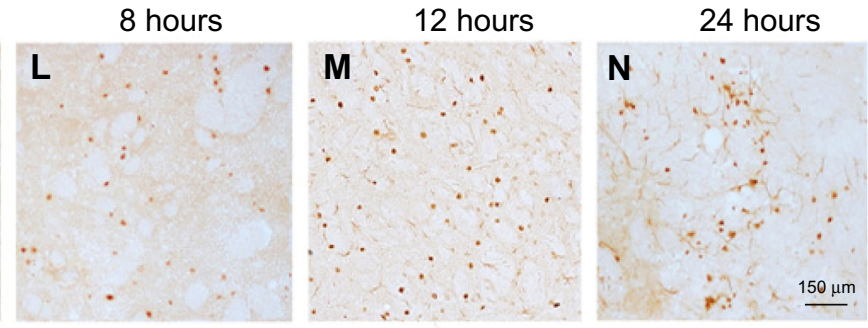

$\operatorname{COX}-2^{f 10 x+f o x}$

Figure 2 Presence of PGIS and CD45 IHC-positive cells following TZG injection.

Notes: (A) PGIS+ cells 12 hours after saline injection in COX-2 flox/flox mice. (B) PGIS+ cells 12 hours after TZG injection into COX-2 flox/flox mice. (C) PGIS+ cells I2 hours after TZG injection into Tie2Cre COX-2 $2^{\text {floxfflox }}$ mice. (D) PGIS+ cells 12 hours after TZG and NS-398 (2 mg/kg) injection into COX-2 flox/fox mice. (E) CD45+ cells I2 hours after saline injection in COX-2 floxfflox mice. (F) CD45+ cells 12 hours after TZG injection into COX-2 ffox/flox mice. (G) CD45+ cells 12 hours after TZG injection into Tie2Cre COX-2 flox/flox mice. (H) CD45+ cells 12 hours after TZG and NS-398 (2 mg/kg) injection into COX-2 floxflox mice. Representative distribution of (I) PGIS+ and (J) CD45+ cells. Time course of appearance of PGIS expressing cells, $4(\mathbf{K}), 8(\mathbf{L}), 12(\mathbf{M})$, and $24(\mathbf{N})$ hours after TZG injection in COX-2 floxfflox mice. Scale bar: I50 $\mu$ m.

Abbreviations: PGIS, prostacyclin synthase; TZG, (RS)-(tetrazol-5-yl)glycine; IHC, immunohistochemistry.

injection (Figure 2C). Further, the low-dose NS-398 pretreatment in $C O X-2^{f f o x f f o x}$ mice, which exacerbates TZG induced neurotoxicity, also abolished the appearance of PGIS+ cells (Figure 2D).

Because the pattern of PGIS+ cells observed in the parenchyma of TZG-treated mice resembles that of the infiltrating leukocytes in the brain, we used IHC with the pan-leukocyte marker CD45 to compare the distribution of PGIS+ cells (Figure 2A-D) with the distribution of CD45+ leukocytes (Figure 2E-H). Unlike PGIS+ cells, $\mathrm{CD} 45+$ cells were still present in Tie2Cre COX-2floxflox mice (Figure 2G) and in low-dose NS-398 pretreated COX-2 $2^{f l o x f f l o x}$ mice (Figure $2 \mathrm{H}$ ). The distributions of PGIS+ and CD45+ cells in TZG treated COX-2floxfflox mice are illustrated in Figure 2I and J. PGIS+ cells were distributed in a more restricted pattern in the injured striatum and corpus 
callosum (Figure 2I); the distribution of CD45+ cells was spread further outside of the lesion core (Figure 2J). A semiquantitative analysis of the density for this IHC labeling is presented in Table 1. To further characterize PGIS expression, the time course of PGIS+ labeling in

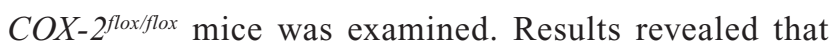
these cells were observed in the brain 8 hours after the TZG injection, and plateaued at 12 hours and 24 hours post-TZG (Figure $2 \mathrm{~K}-\mathrm{N}$ and Table 1).

\section{Identification of PGIS-expressing cell types in the lesion core}

The data suggests that the $\mathrm{PGI}_{2}$ observed in response to excitotoxin administration requires the induction of endothelial COX-2 (and presumably downstream prostanoid/ prostanoids), but that the $\mathrm{PGI}_{2}$ is not produced in the COX2-expressing endothelial cells. We used double-label IHC to identify the PGIS+ cells that were present in the brain parenchyma. PGIS+ cells were found in affected brain parenchyma as early as 8 hours after injury (Figure $2 \mathrm{~K}-\mathrm{N}$ ). Using fluorescent IHC, PGIS+ cells were further analyzed for the coexpression of CD45 (a leukocyte marker), F4/80 (a macrophage marker), or Ly6G (a neutrophil marker) to determine cell type. Results show essentially all the PGIS labeling colocalized with CD45 labeling (Figure 3A-C); 59\% of CD45+ cells are PGIS+. PGIS+ cells and F4/80 cells did not colocalize (Figure 3D-F). In contrast, PGIS+ cells were also positive for Ly6G expression (Figure 3G-I); 57\% Ly6G+ cells are PGIS+. To our surprise, COX-2 expression did not colocalize with Ly6G expression (data not shown). These data suggest that the PGIS+ parenchymal-infiltrating cells are a neutrophil population that does not express COX-2.

In an independent examination of PGIS+ neutrophil migration into the parenchyma following excitotoxin administration, we used the monoclonal antibody $1 \mathrm{~A} 8$ to selectively deplete neutrophils and determined the consequences on PGIS + cell
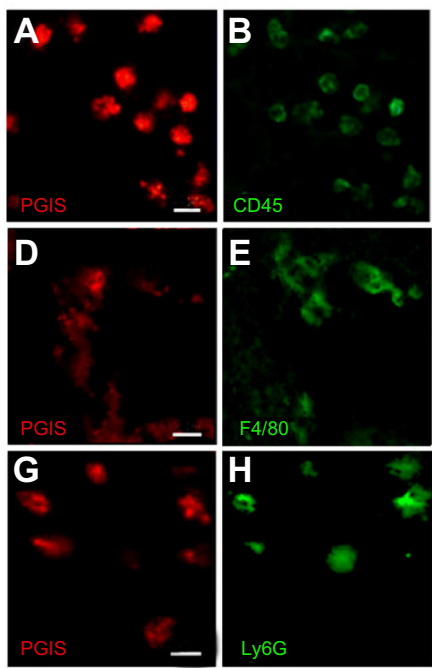

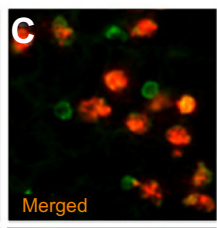

F

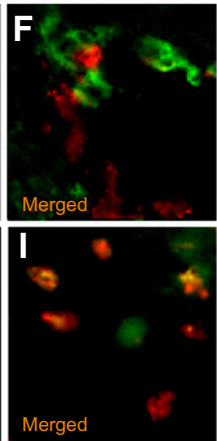

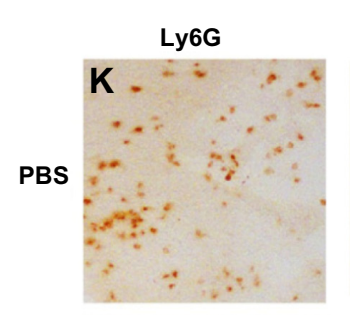

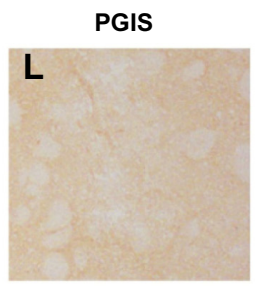

M

$1 \mathrm{A8}$

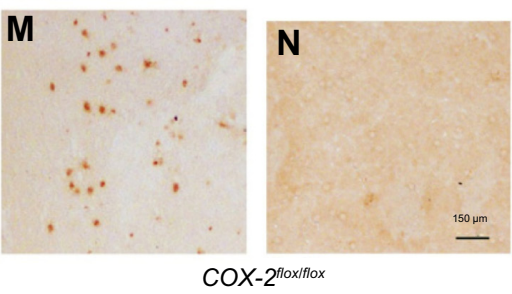

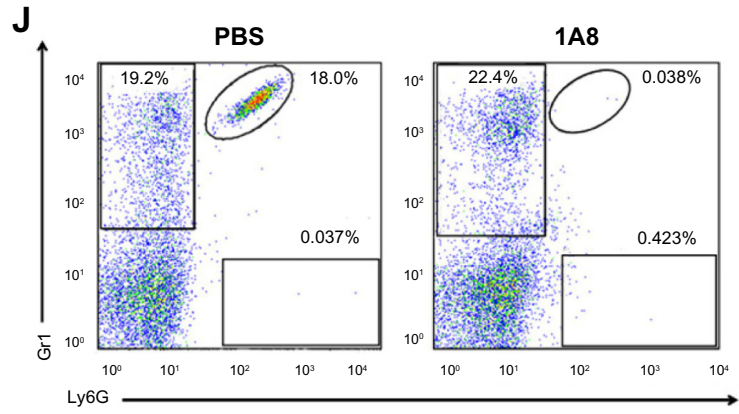

Figure 3 Identification of PGIS expressing cell types in the lesion core.

Notes: PGIS-labeled cells (A, D and G) double labeled with CD45 (B), F4/80 (E), and Ly6G (H). Merged pictographs for PGIS/CD45 (C), PGIS/F4/80 (F), and PGIS/ Ly6G (I) double-positive cells. Scale bars: $25 \mu \mathrm{m}$ (A-I). Representative flow cytometric dot plots of Ly6G-positive/Gr I-positive blood neutrophils (J) from TZG-injected mice following in vivo administration of either neutrophil depleting antibody IA8 or PBS. Ly6G (K and $\mathbf{L})$ and PGIS (M and $\mathbf{N})$ expressing cells in brains of TZG treated mice following PBS (K and $\mathbf{M}$ ) or IA8 ( $\mathbf{L}$ and $\mathbf{N}$ ) treatment. All IHC and flow cytometric assessments were made 12 hours following TZG injections. Scale bars: I50 $\mu$ m. Abbreviations: IHC, immunohistochemistry; PBS, phosphate buffered saline; PGIS, prostacyclin synthase; TZG, (RS)-(tetrazol-5-yl)glycine. 
migration into the lesion area. ${ }^{17}$ Figure $3 \mathrm{~J}$ is a representative bivariate dot plot of Ly6G- and Gr1-stained blood cells from TZG-injected mice that had received prior systemic injections of either $1 \mathrm{~A} 8$ antibody or PBS. Flow cytometric results showed that in the PBS treated control group, 24 hours after intrastriatal TZG injection, neutrophils (Ly6G+/Gr1+ cells) were found in the blood and $1 \mathrm{~A} 8$ antibody treatment depleted these neutrophils (Figure 3J). IHC results further showed that $1 \mathrm{~A} 8$ antibody treatment also successfully depleted both Ly6Glabeled cells (Figure 3K and L) and PGIS+ cells (Figure 3M and $\mathrm{N}$ ) in brains from TZG-treated $C O X-2^{\text {flox } f f o x}$ mice.

\section{$\mathrm{PGI}_{2}$ attenuates TZG-induced calcium influx into neurons}

We next explored the molecular mechanism responsible for the protective effect of $\mathrm{PGI}_{2}$ on excitotoxin-induced neurotoxicity. The $\mathrm{PGI}_{2}$-producing cells in our study were mostly in the lesion core rather than in the vicinity of blood vessels. Whether $\mathrm{PGI}_{2}$ can affect neuronal cells independent of blood flow to exert neuroprotective effects is not known. To this end, we tested whether $\mathrm{PGI}_{2}$ confers neuroprotection by attenuating TZG induced $\mathrm{Ca}^{2+}$ influx, using calcium imaging to monitor neuronal $\mathrm{Ca}^{2+}$ transients in rat striatum slices. Brain slices loaded with Fluo-8, a $\mathrm{Ca}^{2+}$ labeling dye, were exposed to TZG for 30 seconds. Data from representative neurons demonstrated that $\mathrm{TZG}$ induced a marked elevation in intracellular $\mathrm{Ca}^{2+}$ (Figure 4A and B, blue lines). Pretreatment with MRE-269 (the stable $\mathrm{PGI}_{2}$ analogue) for 20 minutes before TZG stimulation significantly reduced $\mathrm{Ca}^{2+}$ influx in the same neuron (Figure 4A, red line). In contrast, pretreatment with ACSF (Figure 4B, red line) had no significant effect on TZG-induced $\mathrm{Ca}^{2+}$ influx. In three repeated experiments, significant differences were demonstrated in both amplitude (Figure 4C) and the area under the
A

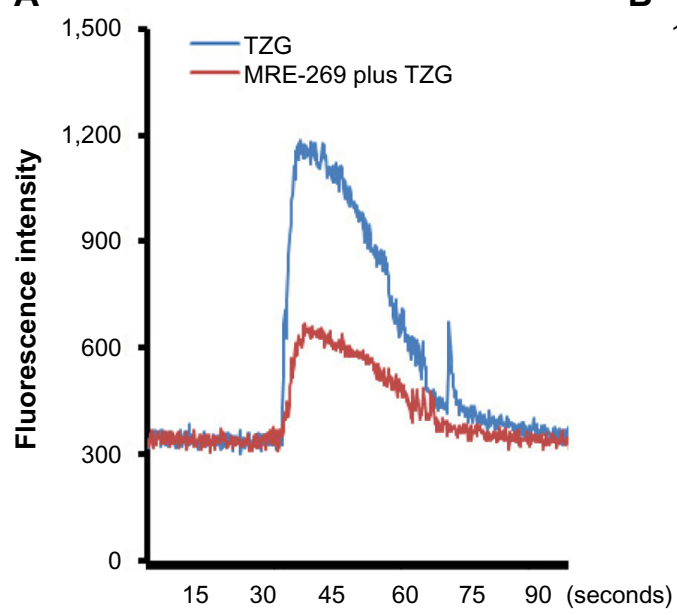

B

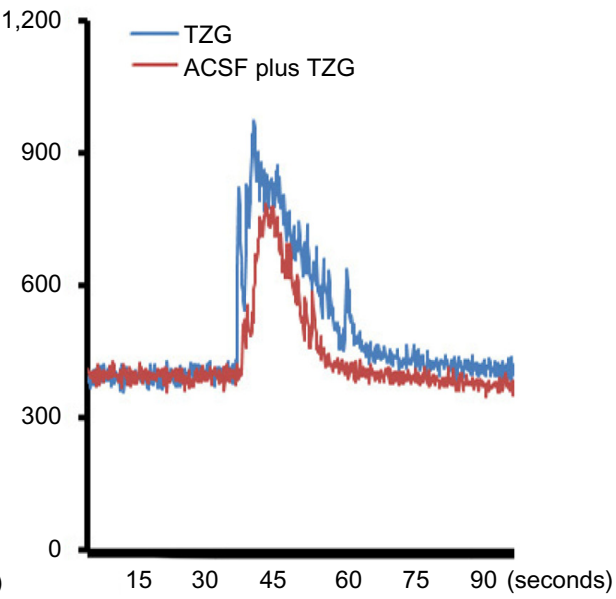

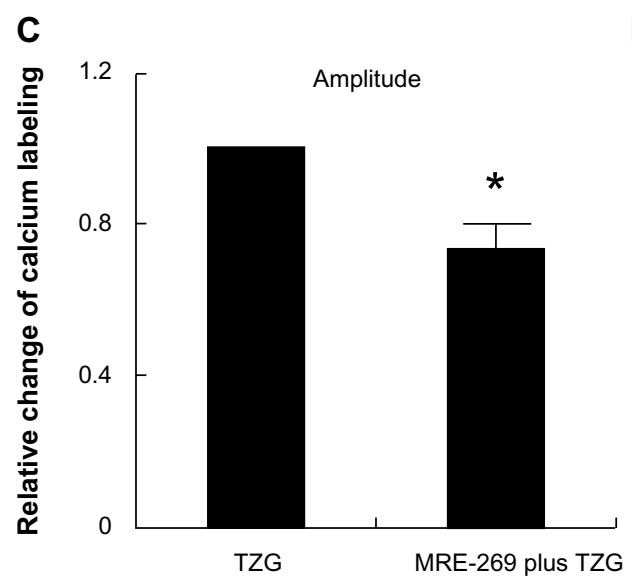

D

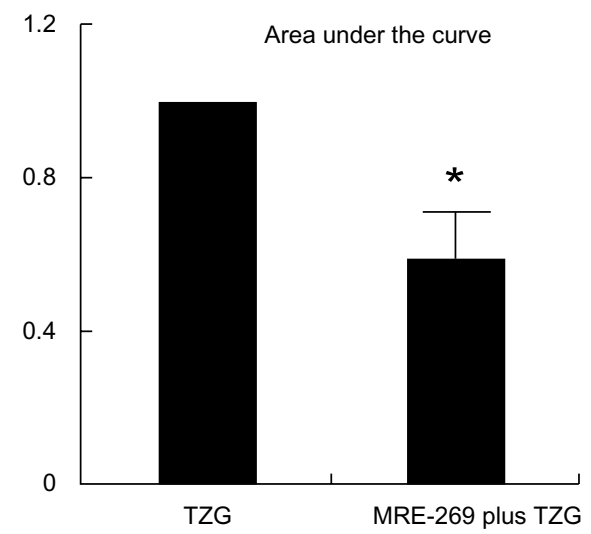

Figure $4 \mathrm{PGI}_{2}$ attenuates TZG-induced calcium influx into neurons.

Notes: (A) A representative neurons' calcium influx induced by ex vivo TZG (blue line) or TZG plus MRE-269 treatment (red line). (B) Neuronal calcium influx induced by ex vivo TZG or ACSF pretreatment before TZG administration (red line). Maximum calcium labeling (amplitude) (C) and area under curve (D) of calcium influx in individual cells after MRE-269 plus TZG and TZG treatment alone. Bars represent group means \pm SEM. *Represents a significant effect of MRE-269 plus TZG compared to TZG treatment alone ( $P \leq 0.0 \mathrm{I}$ for both). $\mathrm{N}=10$ in one slice preparation.

Abbreviations: ACSF, artificial cerebral-spinal fluid; PGI $_{2}$, prostacyclin; SEM, standard error; TZG, (RS)-(tetrazol-5-yl)glycine. 
curve (Figure 4D) for cells that received TZG in the presence of MRE-269 ( $P<0.01$ for both). Cells perfused with MRE269 alone did not display changes in $\mathrm{Ca}^{2+}$ homeostasis (data not shown). Thus, $\mathrm{PGI}_{2}$ protected neurons from TZG-induced toxicity by attenuating the increased $\mathrm{Ca}^{2+}$ influx elicited by the excitotoxin.

\section{Deletion of the COX-2 gene in myeloid cells does not prevent endogenous $\mathrm{PGI}_{2}$ dependent protection from TZG induced neurotoxicity}

LysMCre expression deletes "floxed" DNA sequences in both macrophages and neutrophils. ${ }^{18}$ To further evaluate the cell type/types responsible for the production of the neuroprotective $\mathrm{PGI}_{2}$ following excitotoxin administration, we examined the consequences of TZG injection into LysMCre

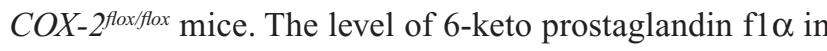

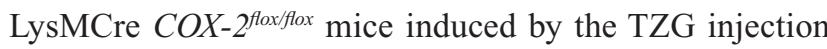

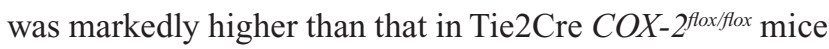
$(P<0.01$; Figure 5A). IHC results also confirmed that PGIS cells were present in the TZG-induced injured striatum in LysMCre $C O X-2^{f l o x}$ fflox mice (Figure 5B) and that low-dose NS-398 pretreatment abrogated the appearance of PGIS cells (Figure 5C) without preventing the arrival of infiltrating leukocytes (Figure 5D and E). Furthermore, NS-398 treatment increased the size of TZG-induced lesions in LysMCre

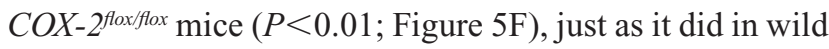
type mice. Tranylcypromine treatment also increased the size of TZG-induced lesions in LysMCre $C O X-2^{f l o x} / f \circ x$ mice $(P<0.01$; Figure 5F). These results are consistent with the suggestion that endothelial COX-2 is essential for the neuroprotective effect.

\section{Discussion}

Our search for a COX-2 dependent neuroprotective mechanism led us to several important observations regarding $\mathrm{PGI}_{2}$. Consistent with previous studies, ${ }^{11,19}$ we found that $\mathrm{PGI}_{2}$ was induced by excitotoxic neural injury and that exogenous $\mathrm{PGI}_{2}$ administration affords neuroprotection. The new findings in the present study are: 1) endogenous $\mathrm{PGI}_{2}$ production mediates nonneuronal COX-2-dependent neuroprotection; 2) $\mathrm{PGI}_{2}$ is produced by a subset of infiltrating neutrophils that populate the lesion core in response to excitotoxin administration; and 3) $\mathrm{PGI}_{2}$ can exert neuroprotective effects by directly reducing NMDA-mediated excess calcium influx. There is a significant clinical implication resulting from the observation that endogenous $\mathrm{PGI}_{2}$ has a neuroprotective effect: the PGIS inhibitor tranylcypromine is also an inhibitor of monoamine oxidase, and this drug is used clinically as an antidepressant; ${ }^{20}$ consequently, patients on tranylcypromine therapy may have an increased risk of exacerbated neural damage in response to acute brain injury.

The identification of PGIS-producing cells as a subset of neutrophils following a neurologic insult is, to our knowledge, a new observation. Previous studies have suggested that vascular cells are a major source of the $\mathrm{PGI}_{2}$ produced in response to neural injury. ${ }^{11} \mathrm{PGI}_{2}$ is an effective vasodilator; one therapeutic mechanism suggested for the efficacy of $\mathrm{PGI}_{2}$-like agonists in treating acute brain injury has been their ability to improve cerebral blood flow to the injured tissue. ${ }^{21}$ Our findings add a previously undescribed, and unexpected, mechanism for the neuroprotective role of $\mathrm{PGI}_{2}$ : the $\mathrm{PGI}_{2}$ produced near the injured neurons by infiltrating neutrophils may directly participate in neuronal rescue. This suggestion is supported by the observation that $\mathrm{PGI}_{2}$ can reduce
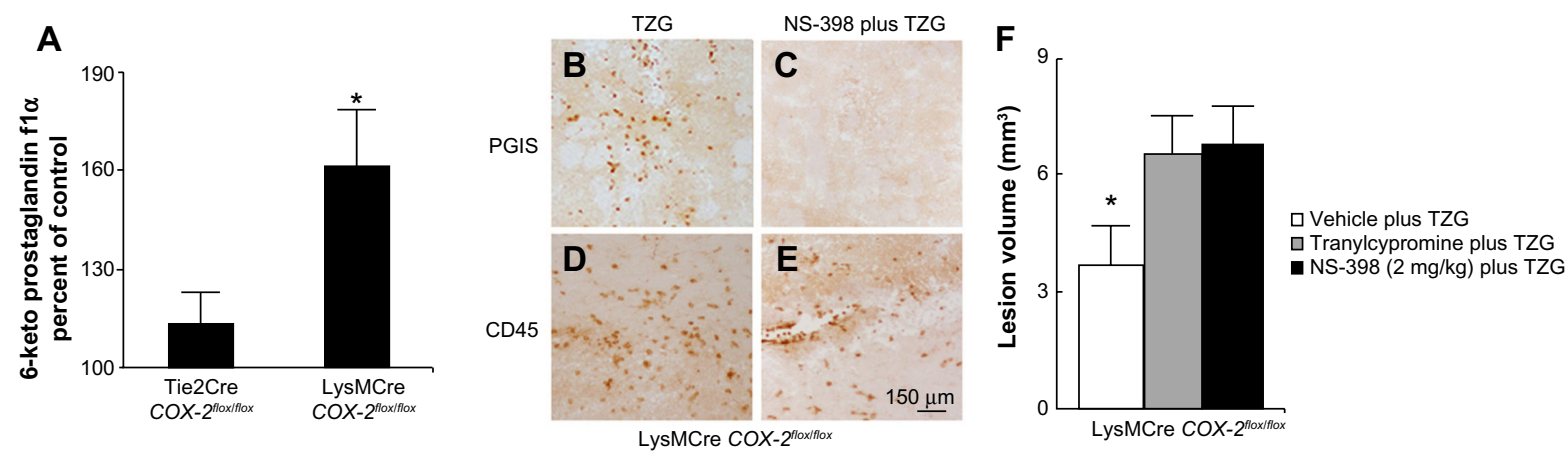

Figure 5 Deletion of the COX-2 gene in myeloid cells does not prevent endogenous $\mathrm{PGI}_{2}$ dependent protection from TZG-induced neurotoxicity.

Notes: (A) The level of 6-keto prostaglandin $\mathrm{fl} \alpha$ in LysMCre COX-2 floxfflox mice compared with Tie2Cre COX-2 $2^{\text {floxfflox }}$ mice 12 hours after TZG injection. (B and C) PGIS- and (D and E) CD45-labeled cells in the injured striatum in LysMCre COX-2 $2^{\text {flox/flox }}$ mice 12 hours after TZG alone or NS-398 plus TZG treatment; scale bar: I50 $\mu$ m. (F) Twentyfour-hour assessment of TZG-induced lesion volume in pretreated tranylcypromine, NS-398, or TZG alone animals. Bars represent group means \pm SEM. *Represents a significant effect compared to all other groups ( $P \leq 0.0$ I for all). $\mathrm{N}=5$ in all experimental groups.

Abbreviations: $\mathrm{PGI}_{2}$, prostacyclin; PGIS, prostacyclin synthase; SEM, standard error; TZG, (RS)-(tetrazol-5-yl)glycine. 
TZG-induced neuronal $\mathrm{Ca}^{2+}$ influx in neurons in the slice preparation, where access to nutrients as a result of blood flow modulation by $\mathrm{PGI}_{2}$ agonists is not limiting. This suggestion is also supported by a previous report that a ligand for the neural specific $\mathrm{PGI}_{2}$ receptor can provide neuroprotection without affecting cerebral vascular $\mathrm{PGI}_{2}$ receptors. ${ }^{19}$ It should be noted that $\mathrm{PGI}_{2}$ could affect multiple calcium channels, to effect NMDA-induced calcium increases. Elucidating the mechanisms by which the direct effects of $\mathrm{PGI}_{2}$ on neurons are mediated will require extensive future studies. In addition, $\mathrm{PGI}_{2}$ may exert neuroprotective effect indirectly via its anti-inflammatory effects. $^{22}$

The relationship, following excitotoxin administration, between the nonneuronal COX-2-expressing cells and the PGIS-expressing cells found in this study has not previously been observed and was, to us, surprising. Because we first found that $\mathrm{PGI}_{2}$ production in response to neurotoxin administration depended upon endothelial COX-2 expression, we presumed - as most current models suggest - that the elevated $\mathrm{PGI}_{2}$ must also be produced in these cells, as a consequent downstream product of COX-2 induction. However, our subsequent observations demonstrated that, instead, PGIS/ $\mathrm{PGI}_{2}$ is produced by infiltrating neutrophils elicited by $\mathrm{TZG}$ administration. Thus, the endothelial COX-2-expression is indirectly connected to the $\mathrm{PGI}_{2}$ production; $\mathrm{COX}-2$ in the endothelial cells plays a required inductive role to elicit $\mathrm{PGI}_{2}$ production by a second cell type, the infiltrating neutrophil. Moreover, COX-2 expression was not detected in these PGIS+ infiltrating neutrophils. These data suggest that, in the infiltrating neutrophils, COX-1, not COX-2, may synthesize the $\mathrm{PGH}_{2}$ precursor of $\mathrm{PGI}_{2}$. Neutrophils are a member of the myeloid series; their COX-2 expression should be eliminated by targeted deletion of the $C O X-2$ gene in LysMCre $C O X-2^{f l o x} / f l o x$ mice. ${ }^{23}$ Recall that TZG-induced neuroprotection is abrogated

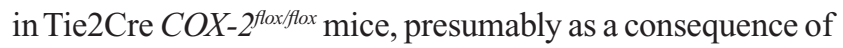
$C O X-2$ gene deletion in endothelial cells. In contrast, deletion of the $C O X-2$ gene in myeloid cells in LysMCre $C O X-2^{f l o x}$ fflox mice had no effect on the neuroprotection to excitotoxin administration that is eliminated either in Tie 2 Cre $C O X-2^{f l o x} f f l o x$ mice or by low dose selective COX-2-inhibitor administration. These data support the suggestions that: 1) COX-1, rather than COX-2, is the cyclooxygenase necessary for neutrophil $\mathrm{PGI}_{2}$ production in response to excitotoxin; and 2) COX-2 expression in cells of the myeloid series is not necessary for neuroprotection in TZG-treated mice.

Two possibilities exist to explain why endothelial COX-2 expression is necessary for recruitment of PGIS-expressing neutrophils: 1) COX-2 expression in the injured vasculature gates the entry of PGIS-expressing cells to the brain parenchyma; or 2) COX-2 expression in the vasculature provides the necessary signal to induce PGIS expression in the neutrophils after they have entered the brain in response to excitotoxin. For either option, without COX-2 expression in the endothelial cells, PGIS-expressing neutrophils are not present and neuroprotection is abrogated. It remains to be determined which of these mechanisms is correct.

In summary, the endothelial COX-2 expression in the lesion core provides neuroprotection by facilitating the arrival of PGIS-expressing neutrophils; the $\mathrm{PGI}_{2}$ produced by these cells reduces excitotoxin-mediated excess calcium influx into affected neurons.

\section{Acknowledgment}

This study was supported by NIH funding RO1 AI076926 to NQ.

\section{Disclosure}

The authors report no conflicts of interest in this work.

\section{References}

1. Hara K, Kong DL, Sharp FR, Weinstein PR. Effect of selective inhibition of cyclooxygenase 2 on temporary focal cerebral ischemia in rats. Neurosci Lett. 1998;256:53-56.

2. Strauss KI, Barbe MF, Marshall RM, Raghupathi R, Mehta S, Narayan RK. Prolonged cyclooxygenase-2 induction in neurons and glia following traumatic brain injury in the rat. J Neurotrauma. 2000;17: 695-711.

3. Koistinaho J, Chan PH. Spreading depression-induced cyclooxygenase-2 expression in the cortex. Neurochem Res. 2000;25:645-651.

4. Adams J, Collaço-Moraes Y, de Belleroche J. Cyclooxygenase-2 induction in cerebral cortex: an intracellular response to synaptic excitation. J Neurochem. 1996;66:6-13.

5. Kaufmann WE, Worley PF, Pegg J, Bremer M, Isakson P. COX-2, a synaptically induced enzyme, is expressed by excitatory neurons at postsynaptic sites in rat cerebral cortex. Proc Natl Acad Sci U S A. 1996;93:2317-2321.

6. An Y, Belevych N, Wang Y, et al. Neuronal and nonneuronal COX-2 expression confers neurotoxic and neuroprotective phenotypes in response to excitotoxin challenge. J Neurosci Res. 2014;92:486-495.

7. Sales KJ, Jabbour HN. Cyclooxygenase enzymes and prostaglandins in pathology of the endometrium. Reproduction. 2003;126:559-567.

8. Liang X, Wu L, Hand T, Andreasson K. Prostaglandin D2 mediates neuronal protection via the DP1 receptor. $J$ Neurochem. 2005;92: 477-486.

9. Cui Y, Takamatsu H, Kakiuchi T, et al. Neuroprotection by a central nervous system-type prostacyclin receptor ligand demonstrated in monkeys subjected to middle cerebral artery occlusion and reperfusion: a positron emission tomography study. Stroke. 2006;37:2830-2836.

10. Gryglewski RJ. Prostacyclin among prostanoids. Pharmacol Rep. 2008;60:3-11.

11. Fang YC, Wu JS, Chen JJ, et al. Induction of prostacyclin/PGI2 synthase expression after cerebral ischemia-reperfusion. $J$ Cereb Blood Flow Metab. 2006;26:491-501.

12. Constien R, Forde A, Liliensiek B, et al. Characterization of a novel EGFP reporter mouse to monitor Cre recombination as demonstrated by a Tie2 Cre mouse line. Genesis. 2001;30:36-44. 
13. Narasimha AJ, Watanabe J, Ishikawa TO, et al. Absence of myeloid COX-2 attenuates acute inflammation but does not influence development of atherosclerosis in apolipoprotein E null mice. Arterioscler Thromb Vasc Biol. 2010;30:260-268.

14. Ishikawa TO, Herschman HR. Conditional knockout mouse for tissuespecific disruption of the cyclooxygenase-2 (Cox-2) gene. Genesis. 2006;44:143-149.

15. Paxinos G, Franklin KB. The Mouse Brain in Stereotaxic Coordinates. Compact 2nd ed. Amsterdam; Boston: Elsevier Academic Press; 2004.

16. Huang Y, Smith DE, Ibáñez-Sandoval O, Sims JE, Friedman WJ. Neuronspecific effects of interleukin-1beta are mediated by a novel isoform of the IL-1 receptor accessory protein. J Neurosci. 2011;31:18048-18059.

17. Daley JM, Thomay AA, Connolly MD, Reichner JS, Albina JE. Use of Ly6G-specific monoclonal antibody to deplete neutrophils in mice. J Leukoc Biol. 2008;83:64-70.

18. Clausen BE, Burkhardt C, Reith W, Renkawitz R, Förster I. Conditional gene targeting in macrophages and granulocytes using LysMcre mice. Transgenic Res. 1999;8(4):265-277.
19. Takamatsu H, Tsukada H, Watanabe Y, et al. Specific ligand for a central type prostacyclin receptor attenuates neuronal damage in a rat model of focal cerebral ischemia. Brain Res. 2002;925:176-182.

20. Frieling H, Bleich S. Tranylcypromine: new perspectives on an "old" drug. Eur Arch Psychiatry Clin Neurosci. 2006;256:268-273.

21. Lundblad C, Grände PO, Bentzer P. Increased cortical cell loss and prolonged hemodynamic depression after traumatic brain injury in mice lacking the IP receptor for prostacyclin. J Cereb Blood Flow Metab. 2008;28:367-376.

22. Wilson SM, Shen P, Rider CF, et al. Selective prostacyclin receptor agonism augments glucocorticoid-induced gene expression in human bronchial epithelial cells. J Immunol. 2009;183:6788-6799.

23. Luyendyk JP, Flanagan KC, Williams CD, et al. Tissue factor contributes to neutrophil CD11 b expression in alpha-naphthylisothiocyanate-treated mice. Toxicol Appl Pharmacol. 2011;250:256-262.

\section{Publish your work in this journal}

The Journal of Inflammation Research is an international, peer-reviewed open-access journal that welcomes laboratory and clinical findings on the molecular basis, cell biology and pharmacology of inflammation including original research, reviews, symposium reports, hypothesis formation and commentaries on: acute/chronic inflammation; mediators of inflamma-

\section{Dovepress}

tion; cellular processes; molecular mechanisms; pharmacology and novel anti-inflammatory drugs; clinical conditions involving inflammation. The manuscript management system is completely online and includes a very quick and fair peer-review system. Visit http://www.dovepress.com/ testimonials.php to read real quotes from published authors.

Submit your manuscript here: http://www.dovepress.com/journal-of-inflammation-research-journal 